\title{
Evidence for $\boldsymbol{H}$-2-Linked Control of Retrovirus Production in Friend Virus-Induced Tumor Cell Lines
}

\author{
JOHN H. WOLFE† AND KENNETH J. BLANK* \\ Department of Pathology and Laboratory Medicine, Division of Research Immunology, University of Pennsylvania \\ School of Medicine, Philadelphia, Pennsylvania 19104
}

Received 21 November 1985/Accepted 24 February 1986

\begin{abstract}
In Friend leukemia virus-induced tumor cell lines derived from mice congenic with respect to the $H-2$ complex, most cell lines expressing the $H-2^{k}$ haplotype continuously produced infectious exogenous virus in culture, whereas most cell lines expressing the $H-2^{b}$ or $H-2^{d}$ haplotype stopped producing virus during in vitro passage. This apparent $H$-2-linked control of virus production did not appear to be the result of alteration of the provirus or resistance to superinfection. The implications of this finding with respect to virus-induced leukemogenesis are discussed.
\end{abstract}

In the mouse, several genes influence susceptibility and resistance to retrovirus-induced leukemogenesis $(33,46,54$, 58). For most retroviruses, one or more of these genes is linked to the major histocompatibility complex, $H-2$, and is associated with the $H-2 K / H-2 I$ or $H-2 D$ region or both (33, $54,46)$. The mechanism for this $H$-2-associated control of susceptibility and resistance to virus-induced leukemogenesis remains poorly understood. In vivo, both immune responses to viral antigens $(5,7,23,24,34,40-42)$ and levels of virus replication $(11,21,32,38,59,64)$ have been shown to be influenced by genes linked to $H-2$. In these experiments, however, it is unclear if the observed control of virus production was a direct effect on some step in the life cycle of the virus or a secondary event perhaps related to the elimination of virus, virus-infected cells, or both, mediated by an immune response controlled by an $H$-2-linked immune-response gene.

To examine the possible direct effects of $H$-2-linked genes on virus expression in the absence of any interaction with the host (e.g., an immune response), we have established a series of cell lines from tumors induced by Friend virus (FV) in BALB mice congenic with respect to the $H-2$ complex. A few cell lines derived from tumors induced in mice from strains other than BALB/c were also examined. Previous studies on a small number of such cell lines suggested that an $\boldsymbol{H}$-2-linked gene(s) might exert intracellular control over virus expression $(18,62,63)$.

We now report that most cultured tumor cell lines derived from mice expressing the $H-2^{k}$ haplotype continued to produce infectious, oncogenic virus of the type used for the initial infection in vivo, whereas most of the cell lines derived from mice expressing the $\boldsymbol{H}-2^{b}$ and $H-2^{d}$ haplotypes stopped producing infectious virus in culture. The few tumor cell lines derived from mice with non-BALB backgrounds exhibited the same pattern of virus production with respect to $H-2$. Thus, these studies suggest that a gene(s) linked to $\mathrm{H}-2$ may control the production of exogenous retroviruses by these cultured tumor cell lines. This control appeared to be exerted at some point in the life cycle of the virus after insertion of the provirus into the mouse genome, because nonproducer tumor cells continued to express virus anti-

\footnotetext{
* Corresponding author.

$\dagger$ Present address: Laboratory of Veterinary Oncology, SloanKettering Institute for Cancer Research, New York, NY 10021.
}

gens, and the production of infectious exogenous virus by nonproducer cells was induced by treatment with iododeoxyuridine (IUdR).

\section{MATERIALS AND METHODS}

Mice. C57BL/10Lil (B10), BALB/c-H-2 $2^{k} / \mathrm{Lil}$ (BALB.K), and BALB/c- $H-2^{b} /$ Lil (BALB.B) mice were bred from pairs obtained from F. Lilly, Albert Einstein College of Medicine, Bronx, N.Y. C57BL/10-H-2 ${ }^{k}(\mathrm{~B} 10 . \mathrm{K})$ mice were bred from pairs obtained from D. Schreffler, Washington University, St.

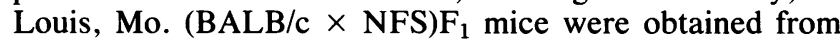
breeding the parent strains obtained from P. O'Donnell and A. Oliff, respectively, Sloan-Kettering Institute, New York, N.Y. BALB/c and $(\mathrm{C} 57 \mathrm{BL} / 6 \times \mathrm{DBA} / 2) \mathrm{F}_{1}$ mice were purchased from the Jackson Laboratory, Bar Harbor, Maine.

Viruses. FV (19) used in these studies was also originally obtained from $\mathrm{F}$. Lilly as an $\mathrm{N} \rightarrow \mathrm{NB}$-tropic virus. Virus stocks were maintained in this laboratory by serial passage in BALB mice inoculated as neonates. Virus stocks were prepared from $10 \%$ homogenates in Hanks balanced salt solution (HBSS) of the greatly enlarged thymus, spleen, and lymph nodes from a susceptible mouse inoculated with a high dose of virus. These homogenates were kept continuously at 0 to $4^{\circ} \mathrm{C}$ and were clarified by centrifugation for 15 $\min$ at $2,400 \times g$. The virus supernatants were stored in $2-\mathrm{ml}$ ampoules at $-70^{\circ} \mathrm{C}$.

Tumor cell lines. All cell lines were produced and passaged in this laboratory, except for the Hfl/b-tc (clone L) and $\mathrm{Hfl} / \mathrm{d}$-tc tumor cell lines (17) which were originally obtained from H. Freedman, Downstate Medical School, Brooklyn, N.Y., and maintained in this laboratory for several years. The tumor cell lines used in this study were established by the following method. Mice were inoculated with FV intraperitoneally as adults. FV produces an erythroid leukemia characterized by splenomegaly in 2 to 3 weeks. These leukemic spleens were removed, minced into single cell suspensions, and seeded in tissue culture flasks in medium containing $10 \%$ fetal calf serum and $10^{-5}$ M 2- $\beta$ mercaptoethanol. Periodically, a portion of the medium was withdrawn, and fresh medium was added.

Detection of viruses. Ecotropic murine leukemia virus was detected in the XC plaque assay described previously (50). SC-1 $\left(5 \times 10^{4}\right)$ cells $(26)$ were seeded in six-well $\left(9.6 \mathrm{~cm}^{2}\right.$ per well) tissue culture plates and incubated at $37^{\circ} \mathrm{C}$ in $5 \% \mathrm{CO}_{2}$ overnight. These cells were incubated for $45 \mathrm{~min}$ in $5 \mu \mathrm{g}$ of 
DEAE-dextran per $\mathrm{ml}$ and washed, and the sample to be tested, either culture supernatant or lethally irradiated $(5,000$ R) tumor cells (infectious center assay), was added. Supernatants were collected by resuspending $100 \%$ viable tumor cells in fresh medium at $10^{6}$ cells per $\mathrm{ml}$, incubating this culture for $18 \mathrm{~h}$ at $37^{\circ} \mathrm{C}$, removing the cells by centrifugation, and storing the supernatant at $-70^{\circ} \mathrm{C}$. These supernatants or cells were removed 2 to $4 \mathrm{~h}$ later, and fresh medium with $10 \%$ fetal calf serum was added. These cultures were fed as needed. When the SC-1 cells were confluent, the medium was removed, the cells were exposed to $25 \mathrm{~s}$ of UV radiation, $10^{6} \mathrm{XC}$ cells in $2 \mathrm{ml}$ of medium were added, and these cultures were incubated at $37^{\circ} \mathrm{C}$ in $5 \% \mathrm{CO}_{2}$ for 3 days. Supernatants were removed, cells were washed, and the cell monolayer was either stained and fixed for $5 \mathrm{~min}$ in a solution of $3 \mathrm{~g}$ of methylene blue stain, $500 \mathrm{ml}$ of methanol, and $100 \mathrm{ml}$ of carbolfuchsin or fixed in methanol for $5 \mathrm{~min}$, dried, and stained with cresyl violet. These stained monolayers were examined for plaques. SC- 1 and XC cells were a gift of J. Hartley, National Cancer Institute, Bethesda, Md.

This method was also used to determine $F v-1$ tropism by employing embryo fibroblasts derived from BALB $\left(F v-1^{b}\right)$,

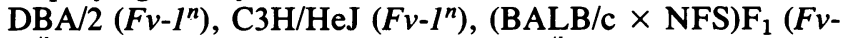
$\left.1^{n / b}\right)$, or $(\mathrm{C} 57 \mathrm{~B} 1 / 6 \times \mathrm{DBA} / 2) \mathrm{F}_{1}\left(F v-1^{n / b}\right)$ mice or NIH-3T3 $\left(F v-I^{n}\right)$ cells as target cells. NIH-3T3 cells were a gift of W. Hardy, Jr., Memorial Sloan-Kettering Institute. Embryo fibroblast lines were established by surgically removing embryos from female mice at 12 to 16 days of gestation, making single cell suspensions from them, and transferring the cells to tissue culture flasks in medium supplemented with $10 \%$ fetal calf serum. These adherent cells were passed as necessary.

FV activity was also measured in vivo by assaying for the formation of spleen foci and splenomegaly (2). Culture supernatants $(0.5 \mathrm{ml})$ from $10^{6}$ cells per $\mathrm{ml}$ growing at the logarithmic phase for $18 \mathrm{~h}$ and passed through a 20- $\mu \mathrm{m}$-pore filter were injected intravenously into the tails of $(\mathrm{C} 57 \mathrm{BL} / 6$ $\times \mathrm{DBA} / 2) \mathrm{F}_{1}\left(F v-1^{n / b}\right)$ mice. Beginning 9 days after infection, mice were palpated for splenomegaly. Mice were sacrificed when splenomegaly developed or at day 14 . Spleens were removed and fixed in Bouin solution, and fixed spleens were compared by size with uninfected spleens from the same strain of mouse. In most cases, spleens were either greatly enlarged (10 to 30 times larger) with confluent foci or indistinguishable from uninfected organs. Spleen foci were enumerated 9 days after intravenous injection of culture supernatants.

Supernatants from virus cultures were tested for the presence of reverse transcriptase as an indication of the presence of virus particles by the oligo(dT) priming method (22). Culture supernatant $(25 \mu \mathrm{l})$ to be tested was mixed with $50 \mu \mathrm{l}$ of $50 \mathrm{mM}$ Tris hydrochloride (pH 8.0), $20 \mathrm{mM}$ 2- $\beta$-mercaptoethanol, $5 \mathrm{mM} \mathrm{MgCl}_{2}, 60 \mathrm{mM} \mathrm{NaCl}, 0.05 \%$ Nonidet P-40, $5 \mu \mathrm{g}$ of oligo(dT) per ml (Sigma Chemical Co., St. Louis, Mo.), $10 \mu \mathrm{g}$ of poly(A) per ml (Sigma), and $20 \mu \mathrm{Ci}$

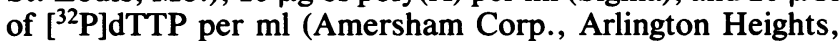
Ill.). This mixture was incubated $2 \mathrm{~h}$ at $37^{\circ} \mathrm{C}$. A 50- $\mu$ l sample was removed and blotted onto DEAE paper (Whatman DE-81; Whatman, Inc., Clifton, N.J.). The filters were washed three times for $30 \mathrm{~min}$ in $2 \times 0.3 \mathrm{M} \mathrm{NaCl}-0.03 \mathrm{M}$ sodium citrate and once in $95 \%$ ethanol, dried, and exposed to X-ray film for 24 to $60 \mathrm{~h}$.

Detection of cell surface class $I$ antigens. Cells were tested for cell surface expression of $\boldsymbol{H}-2$ class I antigens by fluorescence-activated flow cytometry. Antibodies in solution were clarified by centrifugation in a Beckman Airfuge for 25 min before use (approximately $12,000 \times g)$. Cells $\left(1 \times 10^{6}\right.$ to $3 \times 10^{6}$ ) were incubated with monoclonal antibodies at an appropriate dilution for $30 \mathrm{~min}$ at 0 to $4^{\circ} \mathrm{C}$ in a $0.05 \mathrm{M}$ phosphate buffer ( $\mathrm{pH}$ 7.2)-2\% (wt/vol) bovine serum albumin-0.02\% (wt/vol) sodium azide solution (PBA). Cells were washed in PBA three times and incubated with fluoreceinated goat anti-mouse immunoglobulin (TAGO, Burlingame, Calif.). Cells were washed in PBA three times, suspended in PBA, passed through nylon mesh to remove clumped cells, and analyzed in a flow cytometer.

Some of the monoclonal antibodies to class I antigens were gifts of B. Knowles, The Wistar Institute, Philadelphia, Pa. Antibody 11-4.1 detects $H-2 K^{k}$ (43), B22-249 detects $H-2 D^{b}(31)$, Y 3 detects $H-2 K^{k}$ and $H-2 K^{b}(29)$, and 34-2-12S detects $H-2 D^{d}$ (44). Hybridomas producing mouse antimouse class I monoclonal antibodies to the other specificities tested were obtained from the American Type Culture Collection and grown as ascites fluid in pristane-primed BALB/c mice. Antibody $16-1-2$ detects $H-2 K^{k}$ and $D^{k}, 15-5-5$ detects $H-2 D^{k}(44)$, and 20-8-4 detects $H-2 K^{b} D^{b}$ and $K^{d}(45)$.

Analysis of viral proteins. To analyze viral proteins in the tumor cell lines, cells were metabolically labeled with radioactive amino acids, and the viral proteins were specifically immunoprecipitated and resolved on sodium dodecyl sulfate-polyacrylamide gels (10). Cells growing at the logarithmic phase were washed three times in HBSS and incubated in HBSS for $30 \mathrm{~min}$ at $37^{\circ} \mathrm{C}$. Cells were suspended at $2.5 \times$ $10^{6} / \mathrm{ml}$ in methionine-free RPMI 1640 containing $250 \mu \mathrm{Ci}$ of $\left[{ }^{35} \mathrm{~S}\right]$ methionine (Amersham) per $\mathrm{ml}$ and incubated for $2 \mathrm{~h}$ at $37^{\circ} \mathrm{C}$. After incubation, the cells were washed three times in HBSS and suspended at $10^{6}$ cells per $\mathrm{ml}$ in lysing buffer containing $1 \%$ Nonidet P-40, $0.5 \%$ sodium deoxycholate, and $1 \%$ sodium dodecyl sulfate in $0.01 \mathrm{M}$ Tris ( $\mathrm{pH} 7.4)-0.15$ $\mathrm{M} \mathrm{NaCl}(10)$. After $30 \mathrm{~min}$ at $4^{\circ} \mathrm{C}$, the lysate was stored at $-70^{\circ} \mathrm{C}$.

Lysates of $10^{6}$ cells per ml were precleared with $1 \%$ (wt/vol) Formalin-fixed Staphylococcus aureus Cowan 1 at $4^{\circ} \mathrm{C}$ for $30 \mathrm{~min}$ in the presence of fetal calf serum. S. aureus was removed by centrifugation, antiserum was added, and samples were incubated overnight at $4^{\circ} \mathrm{C}$. The goat antiretroviral antisera were obtained from the Viral Oncology Program, National Cancer Institute, Bethesda, Md., and were previously tested for specificity by radioimmunoassay. Lots 79S-771 anti-Raucher gp70, 79S-142 anti-AKR p30, and 77S-095 anti-Raucher p30 were used. $S$. aureus $(1 \%$ [wt/vol]) was added, samples were incubated for $30 \mathrm{~min}$ at $4^{\circ} \mathrm{C}$, and the complexes were removed by centrifugation and washed three times in lysing buffer. The samples were suspended in eluting buffer of $2 \%$ sodium dodecyl sulfate-5\% 2- $\beta$ mercaptoethanol-62.5 mM Tris hydrochloride ( $\mathrm{pH} 7.4)-10 \%$ glycerol $-0.001 \%$ Coomassie brilliant blue and heated to $100^{\circ} \mathrm{C}$ for $2 \mathrm{~min}$.

Slab gel electrophoresis was performed as described previously (30) with $5 \%$ stacking gels and $11 \%$ running gels. The gels were stained with Coomassie brilliant blue in a solution of glacial acetic acid-methanol-water $(1: 4: 5)$, destained in the same solution without dye, treated with $\mathrm{En}^{3} \mathrm{Hance}$ (New England Nuclear Corp., Boston, Mass.), rehydrated, and dried. Dried gels were exposed to X-ray film (Kodak XAR-5) at $-70^{\circ} \mathrm{C}$ for various times.

IUdR induction of proviruses. Nonproducer cell lines were incubated in $200 \mu \mathrm{g}$ of IUdR per ml (18) in the dark at $37^{\circ} \mathrm{C}$ for $24 \mathrm{~h}$; cells were washed, resuspended in growth medium, and cocultured with DEAE-dextran-treated SC-1 cells to amplify any induced viruses. Nonadherent cells used in the cocultivation were removed after $24 \mathrm{~h}$ by washing three 
TABLE 1 . Virus production and $H-2$ class I antigen expression in tumor cell lines induced with FV

\begin{tabular}{|c|c|c|c|c|c|c|c|c|c|}
\hline \multirow{2}{*}{ Cell line ${ }^{a}$} & \multirow{2}{*}{$H-2^{b}$} & \multirow{2}{*}{$\mathrm{Name}^{b, c}$} & \multicolumn{2}{|c|}{ Infectivity } & \multirow[b]{2}{*}{ Tropism } & \multirow[b]{2}{*}{ RT } & \multicolumn{3}{|c|}{ Class I antigen expression } \\
\hline & & & $\mathrm{XC}$ assay $^{d}$ & $\begin{array}{l}\text { Spleno- } \\
\text { megalye }\end{array}$ & & & $\mathbf{K}^{f}$ & $\mathrm{D}$ & KorD \\
\hline 15 & $k$ & BALB.K-FV-1 & $>100$ & $3 / 3$ & NB & + & + & $\mathrm{ND}^{g}$ & + \\
\hline 22 & $k$ & BALB.K-F112-A & 40 & $2 / 3$ & NB & ND & + & ND & + \\
\hline 26 & $k$ & B10.K-FV-A & $>100$ & ND & NB & ND & ND & ND & ND \\
\hline 14 & $k$ & BALB.K-F112-B & 0 & $0 / 3$ & $\mathrm{NA}^{g}$ & ND & + & ND & + \\
\hline 32 & $k$ & BALB.K-F115-A & 30 & $3 / 3$ & NB & + & ND & ND & ND \\
\hline 35 & $k$ & BALB.K-F115-B & 14 & $3 / 3$ & NB & + & ND & ND & ND \\
\hline 36 & $k$ & BALB.K-F115-C & 0 & $0 / 3$ & NA & - & ND & ND & ND \\
\hline 42 & $k$ & BALB.K-F129-A & $>100$ & $3 / 3$ & NB & + & ND & ND & ND \\
\hline 43 & $k$ & BALB.K-F129-B & 49 & $3 / 3$ & NB & + & ND & ND & ND \\
\hline 9 & $b$ & Hf1/b-tc (BALB.B) & 0 & $0 / 2$ & NA & - & + & + & ND \\
\hline 17 & $b$ & BALB.B-F50-D & 0 & $0 / 3$ & NA & ND & + & + & ND \\
\hline 10 & $b$ & B10/Li-F50-A & 0 & $0 / 3$ & NA & ND & + & + & ND \\
\hline 13 & $b$ & BALB.B-F113-C & 0 & $0 / 3$ & NA & ND & + & + & ND \\
\hline 8 & $b$ & BALB.B-F113-D & $>100$ & $6 / 6$ & NB & + & + & + & + \\
\hline 52 & $b$ & BALB.B-FV129-A & 0 & $0 / 3$ & NA & ND & ND & ND & ND \\
\hline 53 & $b$ & BALB.B-FV129-B & 0 & $0 / 3$ & NA & ND & ND & ND & ND \\
\hline 4 & $d$ & Hfl/d-tc (BALB/c) & 0 & $0 / 3$ & NA & - & + & + & ND \\
\hline 19 & $d$ & BALB/c-F97-A & 0 & $0 / 3$ & NA & + & + & + & ND \\
\hline 12 & $d$ & BALB/c-F97-c & 0 & $0 / 3$ & NA & ND & + & + & ND \\
\hline 21 & $d$ & BALB/c-F114-A & $>100$ & $4 / 4$ & NB & + & - & - & ND \\
\hline 18 & $d$ & BALB/c-F97-B & 0 & ND & NA & ND & ND & ND & ND \\
\hline 39 & $d$ & BALB/c-F115-A & 0 & $0 / 3$ & NA & - & ND & ND & ND \\
\hline 45 & $d$ & BALB/c-F115-B & 0 & $0 / 3$ & NA & - & ND & ND & ND \\
\hline 47 & $d$ & BALB/c-F115-C & 0 & $0 / 3$ & NA & - & ND & ND & ND \\
\hline 48 & $d$ & BALB/c-F115-D & 0 & $0 / 3$ & NA & - & ND & ND & ND \\
\hline 57 & $k d$ & $(\mathrm{~B} . \mathrm{K} \times \mathrm{B} / \mathrm{c}) \mathrm{F}_{1}-\mathrm{FV}-1^{h}$ & 0 & $0 / 3$ & NA & - & ND & ND & ND \\
\hline 58 & $k d$ & $(\mathrm{~B} . \mathrm{K} \times \mathrm{B} / \mathrm{c}) \mathrm{F}_{1}-\mathrm{FV}-2$ & 0 & $0 / 3$ & NA & - & ND & ND & ND \\
\hline 59 & $k d$ & $(\mathrm{~B} . \mathrm{K} \times \mathrm{B} / \mathrm{c}) \mathrm{F}_{1}-\mathrm{FV}-3$ & 0 & $0 / 3$ & NA & - & ND & ND & ND \\
\hline 60 & $k d$ & $(\mathrm{~B} . \mathrm{K} \times \mathrm{B} / \mathrm{c}) \mathrm{F}_{1}-\mathrm{FV}-4$ & 0 & $0 / 3$ & NA & $+1-$ & ND & ND & ND \\
\hline 61 & $k d$ & $(\mathrm{~B} . \mathrm{K} \times \mathrm{B} / \mathrm{c}) \mathrm{F}_{1}-\mathrm{FV}-5$ & 17 & $2 / 3$ & NB & + & ND & ND & ND \\
\hline 62 & $k d$ & (B.K $\times$ B/c)F $F_{1}-F V-6$ & 0 & $0 / 3$ & NA & - & ND & ND & ND \\
\hline 63 & $k d$ & $(\mathrm{~B} . \mathrm{K} \times \mathrm{B} / \mathrm{c}) \mathrm{F}_{1}-\mathrm{FV}-7$ & 0 & $0 / 3$ & NA & - & ND & ND & ND \\
\hline
\end{tabular}

${ }^{a}$ All cell lines reported now to be nonproducers were originally found to be nonproducers within 1 year of explantation. Culture times (years) for cell lines prior to study: $>1: 12,13,14,18,19,21,22,32,35,36,39,42,43,47,48,52,53,57,58,59,60,61,62$, and $63 ;>2: 10$ and $17 ;>4: 15 ;>9: 4$ and 9 .

${ }^{b}$ Chi-square values for producers versus nonproducers: all $H-2^{k}$ versus all $H-2^{b}, P<0.01$; all $H-2^{k}$ versus all $H-2^{d}, P<0.005$; BALB.K versus BALB.B, $P<$ 0.05 ; BALB.K versus BALB/c $\boldsymbol{P}<0.01$; BALB.K versus (BALB.K $\times$ BALB/c) $\mathrm{F}_{1}, \boldsymbol{P}<0.025$.

${ }^{c}$ The names read as follows: (i) the mouse strain in which the tumor was induced, except for cell lines 4 and 9 where the strains of origin are listed in parentheses; (ii) the virus used to induce the tumor either FV or F followed by a number indicating the virus preparation; (iii) a letter or number distinguishing cell lines arising from different primary tumors.

${ }^{d} \mathrm{XC}$ plaques per milliliter of cell culture supernatant in which $10^{6}$ viable cells were growing for $18 \mathrm{~h}$. The nonproducer phenotypes of cell lines with $\mathrm{XC}$-negative supernatants were confirmed in infectious center assays.

$e$ The results are listed as incidence of splenomegaly, because the positives all had greatly enlarged spleens with confluent foci.

${ }^{f}$ Monoclonal antibodies were used to detect the various $H-2$ class I molecules: (i) for the $H-2^{k}$ cell lines, $11-4.1$ for $H-2^{k}$, 15-5-5 for $H-2 D^{k}$, and $16-1-2$ for either $H-2 K^{k}$ or $H-2 D^{k}$; (ii) for the $H-2^{b}$ cell lines, Y3 for $H-2 K^{b}, 34-2-12$ for $H-2 D^{b}$, and 20-8-4 for either $H-2 K^{b}$ or $H-2 D^{b}$; (iii) for the $H-2^{d}$ cell lines, $20-8-4$ for $H-2 K^{d}$ and 34-2-12 for $H-2 D^{d}$

${ }^{8} \mathrm{NA}$, Not applicable; ND, not determined.

${ }^{h}(\mathrm{~B} . \mathrm{K} \times \mathrm{B} / \mathrm{c}) \mathrm{F}_{1}=(\mathrm{BALB} . \mathrm{K} \times \mathrm{BALB} / \mathrm{c}) \mathrm{F}_{1}$.

times. The adherent SC-1 cells were passed several times and tested for the presence of virus in the XC assay. Supernatants from these cultures were passed through 0.45 $\mu \mathrm{m}$-pore filters, and virus was analyzed for tropism on embryo fibroblasts with different $F v-l$ genotypes.

Superinfection. Cell-free FV was obtained from filtered $(0.20 \mu \mathrm{m})$ culture supernatants of confluent BALB.K-FV-1 (cell line 15) tumor cells. These supernatants were used to infect cultured nonproducer tumor cells treated $24 \mathrm{~h}$ previously with Polybrene $(4 \mu \mathrm{g} / \mathrm{ml})$. Control cells were incubated with Polybrene and given supernatant from cell line 14 (a nonproducer cell line). These tumor cells were then passaged for 1 week, at which time culture supernatants were harvested and used in the spleen focus assay (2) with NFS
( $N$ type) and BALB/c (B type) mice. Dilutions of the supernatant were tested to give countable numbers of spleen foci.

\section{RESULTS}

Determination of virus production. The $\mathrm{XC}$ assay was used to test supernatants of the various cultured tumor cell lines for the presence of shed infectious FV (Table 1). Seven out of nine cell lines derived from mice expressing the $\mathrm{H}-2^{k}$ haplotype (Table 1) continuously produced infectious virus in cultures (producer cells). Cell line 26 was derived from B10.K mice, and the others were derived from BALB.K mice. In contrast, one of the seven cell lines derived from mice expressing the $\mathrm{H}-2^{b}$ haplotype (Table 1 ), one of which 


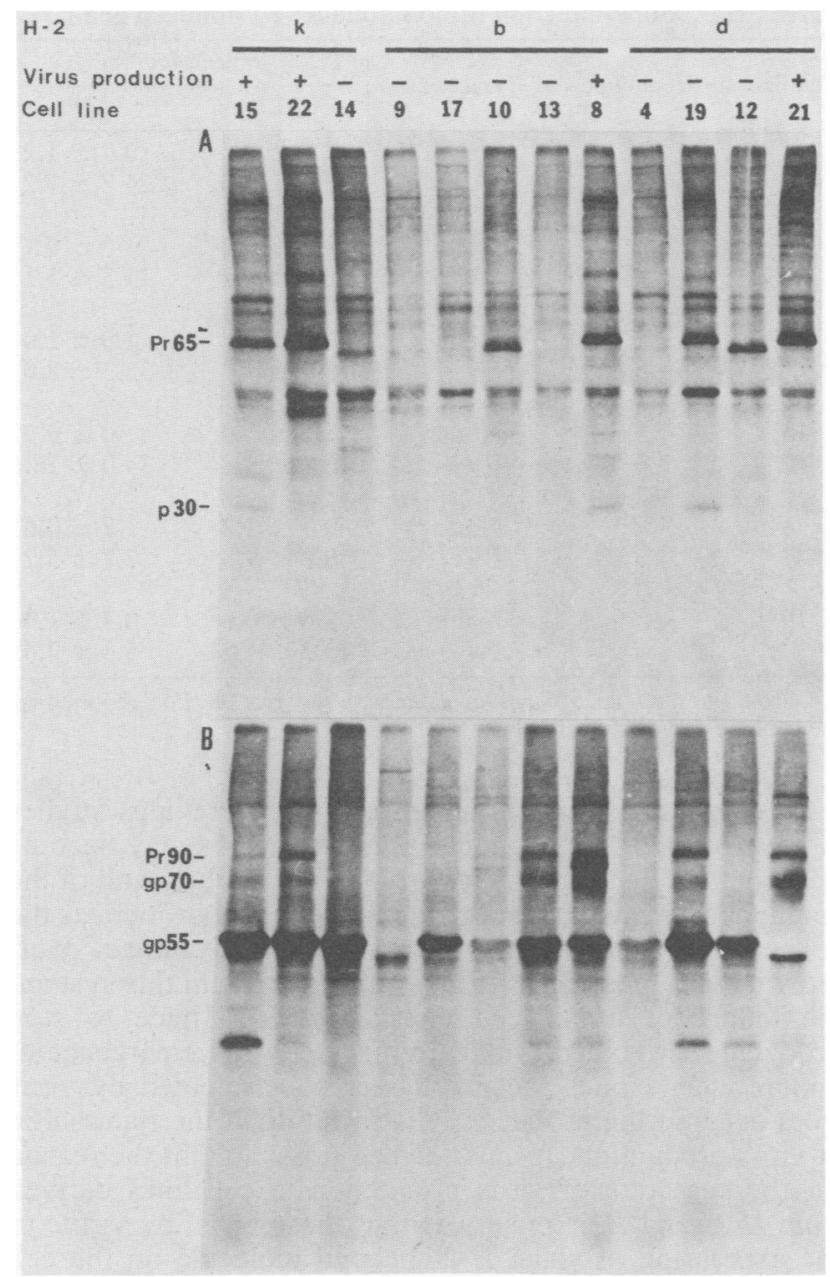

FIG. 1. Sodium dodecyl sulfate-polyacrylamide gel electrophoresis of viral proteins from tumor cell lines. The lane numbers correspond to cell line numbers. Cells were metabolically labeled with $\left[{ }^{35}\right.$ S]methionine and precipitated with either goat anti-p30 (A) or goat anti-gp70 (B) antiserum.

was from a C57BL/10 mouse, and one of nine cell lines derived from mice expressing the $\boldsymbol{H}-2^{d}$ haplotype (Table 1) were producing infectious murine leukemia virus (nonproducer cells). In addition, failure to produce virus was observed in six out of seven (BALB.K $\times$ BALB/c) $F_{1}$ FV-induced tumor cell lines, a failure similar to that observed in tumor cell lines derived from parent BALB/c mice; thus, the failure to produce virus continuously appears to be a dominant trait. These observed differences between $\boldsymbol{H}-2^{k}$ tumor cell lines and $H-2^{b}, H-2^{d}$, and $\mathrm{H}-2^{b / d}$ lines are statistically significant (Table 1 , footnote $b$ ). The nonproducer phenotype of cell lines with XC-negative supernatants was confirmed in an infectious center assay, using $10^{6}$ viable tumor cells to infect the fibroblasts (data not shown). In addition, inoculation of susceptible animals with supernatants from nonproducer cultures caused no disease, which typically occurred when supernatants from virus-producer cell lines were used (Table 1).

Although not all of the cell lines were tested for virus production upon initial explanation, those nonproducer cell lines which had been tested early in their passage history (cell lines 4, 9, 13, 19, 36, 39, 45, 47, 48, 52, 53, 57, 58, and 62) were producing virus upon explantation and stopped producing virus during in vitro passage. Cessation of virus production appeared to be a relatively stable event, because no nonproducer cell lines were found to revert to the producer phenotype, although sporadic low levels of infectious virus were observed in cell line 13 and have been reported previously in cell line 4 (4).

The virus shed by the producer tumor cell lines was determined by two of its properties to be the exogenous virus used to induce the tumor in vivo. (i) The virus harvested from the supernatants induced a rapid splenic enlargement typical of Friend disease. (ii) The virus retained the NB tropism of the inducing virus, as demonstrated by the fact that the virus produced approximately the same number of XC plaques when tested on cells from $F v-1^{b / b}, F v-1^{n / n}$, and heterozygous $F v-1^{n / b}$ mice (Table 2, cell line 15; data for the other producer cell lines are not shown). Because all endogenous viruses are either N or B tropic (58), the NB-tropic virus in the supernatants must have been the progeny of the original exogenous virus used for infection in vivo.

Alterations in viral proteins in nonproducer cell lines. Protein expression in cell lines in this study was analyzed by specific immunoprecipitation of virus proteins from metabolically labeled cells with anti-p30 and anti-gp70 antisera (Fig. 1). The producer cell lines (cell lines 8, 15, 21, and 22) appeared to make the expected viral proteins $\mathrm{gPr} 95^{\mathrm{gag}}$, gPr85 ${ }^{\text {gag }}$, Pr65 gag, p30, Pr180 gag-pol, Pr90 env, and gp70 (13). As has been described previously for virus-producing primary tumor cells (15), gp70 was difficult to detect in the producer cell lines, and p30 was not always readily seen but could usually be identified by overexposing the gels. The spleen focus-forming virus-encoded gp $52 / 55$ was found in all of the FV-derived cell lines regardless of the producer status (Fig. 1) (only gp52 is observed in cell lines 9, as previously described [1], and 21).

In contrast to the producer cell lines, at least one defect in viral protein expression was observed in each of the nonproducer cell lines (Fig. 1). The most common type of defect appeared to be the failure to make precursor polyproteins. No protein corresponding to Pr65 gag was seen in cell line 13 , no proteins corresponding to $\operatorname{Pr} 90^{\text {env }}$ were detected in cell line 10,12 , or 14 , and neither of these precursor polyproteins was seen in cell line 4, 9, or 17 (Fig. 1). Of the cell lines which did not have detectable Pr65gag, however, cell lines 4 and 17 appeared to express anti-p30 precipitable proteins of 85 or 95 kilodaltons or both, (21) which are usually associated with the cell membrane (14, 60).

Some of the nonproducer cell lines expressed aberrant viral proteins. In cell lines 10,12 , and 14 , the proteins which appeared to correspond to Pr65 ${ }^{\text {gag }}$ were small compared with producer cells (Fig. 1). Additionally, cell line 18 expressed a protein of approximately 36 kilodaltons which was precipitated by anti-p30 antiserum and two low-molecular-weight proteins precipitated by anti-gp70 antiserum (data not shown).

To determine if the protein profiles of these nonproducer cell lines reflected either identical defects which occurred in each clone of the line or a composite of defects expressed in different clonal populations, the production of viral proteins was examined in eight cloned tumor cell lines derived from cell lines $13\left(H-2^{b}\right)$ and $12\left(H-2^{d}\right)$ (four clones from each parent cell line). The protein profile of each of these clones was identical to that observed in the parent cell line (data not shown), suggesting that each clone in these nonproducer tumor cell lines expressed the same defect in viral protein production. 
The changes in viral protein expression observed in the nonproducer cell lines were highly variable, and no single change was observed which was associated with all of the nonproducer cell lines nor were any haplotype-specific changes identified. The extent and variety of the alterations found in viral proteins in these cells and others $(1,36,49$, $63)$, including clonal variations $(4,9)$, suggest that their expression may be highly unstable. In contrast, precipitations performed on the same cell line at various intervals extending over a period of several years after the cells have become nonproducers have demonstrated that after the initial aberrations were first observed, no further changes occurred (data not shown). This apparent stability may reflect the emergence of dominant nonproducer clones which are under no selective pressure for change once the gag and the env pathways have been altered.

$\boldsymbol{H}-2$ class I antigen expression. It was of interest to determine if any relationship existed in these cell lines between the expression or production or both of virus and class $\mathrm{I} \boldsymbol{H}-2$ encoded molecules. Some class I molecules become incorporated into $\mathrm{FV}$ particles, indicating that these molecules may be physically associated with viral proteins $(8)$. We did not observe any apparent class I major histocompatibility complex proteins coprecipitating with viral antigens (Fig. 1), nor have any apparent viral antigens been coprecipitated with class I molecules from these cell lines (B. Spear and K. Blank, unpublished observations). Thus in these studies there was no evidence for a strong interaction between these proteins.

Expression of class I molecules in these FV-induced erythroleukemia cell lines appeared to be normal (with the exception of cell line 21), in contrast to previous studies in which altered cell surface expression of class I major histocompatibility complex antigens has been reported in several cultured lymphoid tumor cell lines in vitro $(28,39,48,52$, 53).

Inducibility of the exogenous provirus in nonproducer cell lines. Altered provirus DNA might have produced the defects in virus production and virus protein expression observed in these FV-induced tumor cell lines $(12,55)$. To determine if the provirus of the exogenous virus was still present in the genome of these tumor cells in a form which could lead to the production of a biologically active virus, several nonproducer tumor cell lines were treated with IUdR and tested for the production of exogenous, NB-tropic virus. Four out of the five nonproducer tumor lines tested began producing NB-tropic virus (Table 2), suggesting that the proviruses of the original exogenous NB-tropic viruses used for infection in vivo were not altered in these nonproducer cell lines in a manner which inhibited induction by IUdR.

TABLE 2. Replication in fibroblasts of viruses recovered after IUdR treatment of nonproducer cell lines

\begin{tabular}{cccc}
\hline \multirow{3}{*}{ Cell line } & \multicolumn{3}{c}{ XC plaques/ml of culture supernatant in fibroblasts with } \\
& \multicolumn{3}{c}{$\boldsymbol{v}-\boldsymbol{l}$ genotype: } \\
\cline { 2 - 4 } & $\begin{array}{c}\text { BALB.K-ef } \\
b / b\end{array}$ & $\begin{array}{c}\text { (BALB/c } \times \text { NFS) } \text { F }_{1} \text {-ef } \\
b / n\end{array}$ & $\begin{array}{c}\text { NIH-3T3 } \\
n / n\end{array}$ \\
\hline $15^{a}$ & 64 & 84 & 92 \\
4 & 144 & 103 & 166 \\
13 & 325 & 28 & 3 \\
17 & 103 & 106 & 114 \\
18 & 225 & 163 & 107 \\
19 & 280 & 141 & 165 \\
\hline
\end{tabular}

${ }^{a}$ Supernatants from untreated producer cell line 15 were tested in the same assay and are included for comparison.
TABLE 3. Superinfection of nonproducer FV-induced cell lines

\begin{tabular}{|c|c|c|c|c|}
\hline \multirow{2}{*}{ Cell line } & \multirow{2}{*}{ Haplotype } & \multirow{2}{*}{ Treatment } & \multicolumn{2}{|c|}{ Spleen foci ${ }^{a}$ in: } \\
\hline & & & $\mathrm{BALB} / \mathrm{c}$ & NFS \\
\hline 14 & $\begin{array}{l}k \\
k\end{array}$ & $\begin{array}{l}\text { None } \\
\text { FV }\end{array}$ & $\begin{aligned} 0 & \pm 0 \\
31.7 & \pm 9.0\end{aligned}$ & $\begin{array}{r}0.7 \pm 1.2 \\
21.7 \pm 7.2\end{array}$ \\
\hline 36 & $\begin{array}{l}k \\
k\end{array}$ & $\begin{array}{l}\text { None } \\
\text { FV }\end{array}$ & $\begin{array}{r}0.7 \pm 0.6 \\
38.3 \pm 6.7\end{array}$ & $\begin{aligned} 0 & \pm 0 \\
11.3 & \pm 3.1\end{aligned}$ \\
\hline 17 & $\begin{array}{l}b \\
b\end{array}$ & $\begin{array}{l}\text { None } \\
\text { FV }\end{array}$ & $\begin{array}{c}0 \pm 0 \\
8.0 \pm 7.9\end{array}$ & $\begin{array}{r}1.0 \pm 1.0 \\
33.3 \pm 8.0\end{array}$ \\
\hline 13 & $\begin{array}{l}b \\
b\end{array}$ & $\begin{array}{l}\text { None } \\
\text { FV }\end{array}$ & $\begin{array}{r}1.0 \pm 1.0 \\
16.3 \pm 3.8\end{array}$ & $\begin{aligned} 0 & \pm 0 \\
34.0 & \pm 16.6\end{aligned}$ \\
\hline 4 & $\begin{array}{l}d \\
d\end{array}$ & $\begin{array}{l}\text { None } \\
\text { FV }\end{array}$ & $\begin{array}{r}0.7 \pm 1.2 \\
10.0 \pm 9.8\end{array}$ & $\begin{array}{l}1.7 \pm 0.6 \\
7.7 \pm 5.7\end{array}$ \\
\hline 19 & $\begin{array}{l}d \\
d\end{array}$ & $\begin{array}{l}\text { None } \\
\text { FV }\end{array}$ & $\begin{array}{c}1.0 \pm 0.0 \\
23.7 \pm 18.1\end{array}$ & $\begin{array}{l}0.7 \pm 1.2 \\
5.0 \pm 2.0\end{array}$ \\
\hline
\end{tabular}

${ }^{a}$ Groups of three mice were inoculated with supernatant. Foci reported are the mean \pm standard deviation.

Superinfection of nonproducer cell lines. Previous studies have suggested that producer tumor cell lines may become nonproducer lines during in vitro passage as the result of the spontaneous emergence of nonproducer clones which, as the consequence of some unknown selective advantage, overgrow the producer cells. If this were the case in this system, the failure of tumor cell lines from $H-2^{k}$ mice to stop producing virus might indicate that upon the emergence of nonproducer clones these cells are superinfected by virus from neighboring producer cells resulting in the reinitiation of virus production. It thus seemed possible that the reason for the cessation of virus production in cell lines derived from $H-2^{b}$ and $H-2^{d}$ mice was that these cells, by virtue of the expression of some $\boldsymbol{H}$-2-encoded molecule on the cell surface, were resistant to superinfection.

To test this possibility, nonproducer FV-induced tumor cells were incubated with cell-free supernatants from an $H-2^{k}$ producer tumor cell line and examined for reinitiation of virus production in the spleen focus assay. The results indicated that $\boldsymbol{H}-2^{d}, \boldsymbol{H}-2^{b}$, and $\boldsymbol{H}-2^{k}$ nonproducer cell lines upon superinfection began once again to shed infectious virus (Table 3 ). Therefore, the cell surface $H-2$ molecules expressed by particular tumor cells did not seem to affect the ability of these cells to become superinfected.

\section{DISCUSSION}

The data presented in this report suggest that a host cell gene(s) linked to $\mathrm{H}-2$ controls production of exogenous retroviruses in cultured tumor cell lines induced by FV; i.e., tumor cells expressing the $\boldsymbol{H}-2^{k}$ haplotype continue to produce infectious progeny virus, whereas those expressing the $H-2^{b}$ or $H-2^{d}$ haplotype ceases to produce virus. The cessation of virus production was observed to be a dominant trait in tumor cells derived from $\mathrm{H}-2^{k / d} \mathrm{~F}_{1}$ mice. In the few cell lines with non-BALB/c backgrounds, virus expression showed the same relationship to $H-2$ haplotype expression as in the BALB-derived cell lines. This control does not appear to be exerted at the DNA level through alteration of the provirus, since FV production could be induced in nonproducer cells by treatment with IUdR. The facts that all tumor cells examined upon explantation regardless of $\mathbf{H - 2}$ haplotype expression were initially producing virus and that cessation of virus production occurred during in vitro pas- 
sage suggest that control of virus production is an intracellular event unrelated to the immune response of the host to virus determinants. Thus it appears possible that this control may be exerted at the level of transcription, translation, or posttranslational modification. In fact, evidence for cessation of transcription of the Friend murine leukemia virus component of FV has been described previously in cell lines 4 and 9 (3). The continued expression of viral proteins, however, especially gp55/52 which is spleen focus-forming FV specific, indicates that transcription of some viral proteins continues in all the cell lines regardless of their $\mathrm{H}-2$ haplotype.

The apparent randomness in the phenotypic expression of viral proteins in these tumor cell lines and among clones from nonproducer cell lines $(4,10)$ suggests that the observed influence on virus expression may be secondary to some intracellular reaction mediated by the $\boldsymbol{H}$-2-linked gene(s). This event may be some normal cellular biochemical event which is utilized by the virus for its expression. One candidate for this role might be a gene encoding a product involved in some step in a glycosylation pathway because both viral and $\mathrm{H}-2$ proteins are glycosylated, and genes encoding enzymes associated with glycosylation have been mapped within or near $H-2(16,56)$.

Because the $H-2^{k}$ haplotype is associated with both susceptibility to FV in vivo and virus production in vitro, this apparent $\boldsymbol{H}$-2-mediated direct effect on virus replication may be important in leukemogenesis (62). A necessary hypothesis then is that this control of virus production in cultured tumor cell lines induced with high doses of virus reflects the events which occur in vivo with low virus doses at which differences in $\boldsymbol{H}$-2-linked resistance are observed $(33,46)$. Accordingly, when mice are inoculated with low doses of murine leukemia virus, target cells in $\boldsymbol{H}-2^{k}$ mice may begin to produce virus which causes recruitment of new tumor cells and severely affects the anti-tumor immune response as described below, whereas target cells in resistant $\boldsymbol{H}-2^{b}$ mice may repress virus production enabling them to generate an effective immune response to virus-infected cells. It is unlikely that this $H$-2-linked genetic control of virus production is the only $\boldsymbol{H}$-2-linked effect which governs susceptibility. If it were the only such control, those haplotypes associated with cessation of virus production would also be associated with resistance to that virus. However, the $\boldsymbol{H}-2^{d}$ haplotype, which has been demonstrated in these studies to be associated with the cessation of virus production in FV-induced tumor cells, is associated with susceptibility to FV. Thus in $H-2^{d}$ mice, virus production may be inhibited when small doses of virus are given for infection, but there may be a failure in the ability of the animal to generate an effective immune response to those cells which have become infected (and ultimately transformed) by FV because of the expression of an $\boldsymbol{H}$-2-linked immune response gene. This same immune response gene would conceivably be responsible for an effective anti-FV response in $H-2^{b}$ mice. It is also important to note that not all $\boldsymbol{H}-2^{k}$ cell lines are producers, and not all the $\boldsymbol{H}-2^{b}$ and $H-2^{\mathrm{d}}$ lines are nonproducers, which may reflect the original observations in vivo that $\boldsymbol{H}-2$ mediated resistance was only relative, not absolute.

Several previous observations related to $\mathrm{H}-2$ and the expression of retroviruses or retrovirus-related proteins suggest that $\boldsymbol{H}$-2-linked genes may exert a regulatory influence on provirus expression in untransformed cells. (i) The $\mathbf{H}-2$ linked $C v x-1$ gene appears to control the level of expression in vivo of xenotropic virus from the $B v x-1$ locus on chromosome 1 , and no immune responses were found which could have accounted for this control (64). (ii) In somatic cell hybrids, chromosome 17 (which encodes the $H-2$ complex) appears to be necessary but not sufficient to permit replication of exogenous ecotropic $(20,51)$ and mink cell focusforming (20) viruses. (iii) Expression of the $G_{I X}$ antigen, associated with endogenous gp70 molecules, segregates with both $H-2$ on chromosome 17 and $F v-1$ on chromosome 4 (57). (iv) $H-2$ genes appear to influence the transcription of endogenous spleen focus-forming FV-related sequences in spleen cells from uninfected mice (35).

There are several ways in which altered expression of the exogenous retrovirus by the host cell could potentially affect processes which are thought to be involved in leukemogenesis. (i) Immune responses have been shown to be affected by the presence of virus particles $(6,47)$ and by alteration of viral proteins on the cell surface (25). Viral protein alterations have been observed in all nonproducer tumor cell lines examined (Fig. 1) $(1,10,36,47,49,63)$, which suggests that infected host cells may be capable of altering their antigenic expression. (ii) The binding of recombinant viruses to cell surface receptors may contribute to the leukemogenic process through chronic mitogenic stimulation of target cells (37). Altering the level of virus production could change the amount of mitogenic stimulation thus altering the final incidence of leukemia. (iii) The $\boldsymbol{H}$-2-mediated control of virus production may affect the spread of the virus infection in the host. This effect would result in a reduction in the number of target cells transformed as the result of infection. Because $\mathrm{H}$-2-mediated control of leukemogenesis is only observed with relatively low virus doses $(33,46)$, it would appear that inoculation of high virus doses may overcome these possible effects.

\section{ACKNOWLEDGMENTS}

We thank E. Blankenhorn, D. Boettiger, N. Famulari, M. Halpern, W. Hardy, B. Knowles, and P. O'Donnell for gifts of materials and helpful discussions. FACS analysis was performed by Alan Pickard and J. Faust. Our special thanks to Val Rementer for her good humor and patience in the preparation of this manuscript.

This work was supported by Public Health Service grant CA-15822 from the National Cancer Institute and a grant from the Cancer Research Institute, Inc. J.H.W. was supported by the Veterinary Medical Scientist Training Program, Public Health Service grant GM-07170 from the National Institutes of Health. K.J.B. is the recipient of a Leukemia Society of America Scholar Award.

\section{LITERATURE CITED}

1. Anand, R., F. Lilly, and S. Ruscetti. 1981. Viral protein expression in producer and nonproducer clones of Friend erythroleukemia cell lines. J. Virol. 37:654-660.

2. Axelrad, A. A., and R. A. Steeves. 1964. Assay for Friend leukemia virus: rapid quantitative method based on enumeration of macroscopic spleen foci in mice. Virology 24:513-518.

3. Berkower, A. S., F. Lilly, and R. Soeiro. 1980. Expression of viral RNA in Friend virus-induced erythroleukemia cells. Cell 19:637-642.

4. Berkower, A. S., F. Plata, R. Anand, F. Lilly, and R. A. Steves. 1980. Progressive shutdown of viral gene expression in Friendvirus-induced erythroleukemia cells. Cold Spring Harbor Symp. Quant. Biol. 44:887-892.

5. Blank, K. J., H. Freedman, and F. Lilly. 1976. T-lymphocyte response to Friend virus-induced tumor cell lines in mice of strains congenic at $H-2$. Nature (London) 260:250-252.

6. Bluestone, J. A., and C. Lopez. 1982. Induction of gp70-specific suppressor T-cells in mice inoculated with virus-producing tumor cells. J. Natl. Cancer Inst. 69:953-959.

7. Britt, W. J., and B. Chesebro. 1983. $H-2 D$ control of recovery from Friend virus leukemia: $\boldsymbol{H}-2 D$ region influences the kinetics of the T lymphocyte response to Friend virus. J. Exp. Med. 
157:1736-1745.

8. Bubbers, J. E., and F. Lilly. 1977. Selective incorporation of $\boldsymbol{H}$-2 antigenic determinants into Friend virus particles. Nature (London) 266:458-459.

9. Chesebro, B., J. K. Collins, K. Wehrly, J. Nishio, and M. Cloyd. 1981. Expression of cell surface Friend virus gp70 does not block reinfection by ecotropic murine leukemia viruses. Virology 115:125-129.

10. Collins, J. K., and B. Chesebro. 1980. Spontaneous cessation of Friend murine leukemia virus production by leukemia cell line Y57: overgrowth by non-producer cells. J. Natl. Cancer Inst. 64:1153-1159.

11. Colombatti, A., A. Dux, A. Berns, P. Dement, and J. Hilgers. 1979. $\mathrm{H}$-2-dependent regulation of the high level of expression of ecotropic murine leukemia virus. J. Natl. Cancer Inst. 63: 869-873.

12. Crawford, S., and S. P. Goff. 1984. Mutations in gag proteins P12 and P15 of Moloney murine leukemia virus block early stages of infection. J. Virol. 49:909-917.

13. Dickson, C., R. Eisenman, H. Fan, E. Hunter, and N. Teich. 1982. Protein biosynthesis and assembly, p. 513-648. In $R$ Weiss, N. Teich, H. Varmus, and J. Coffin (ed.), RNA tumor viruses: molecular biology of tumor viruses, 2nd ed. Cold Spring Harbor Laboratory, Cold Spring Harbor, New York.

14. Evans, L. H., S. Dresler, and D. Kabat. 1977. Synthesis and glycosylation of polyprotein precursors to the internal core proteins of Friend murine leukemia virus. J. Virol. 24:865-874.

15. Famulari, N. G., and D. Cieplensky. 1984. A time course study of MuLV env gene expression in the AKR thymus: quantitative analysis of ecotropic and recombinant virus gene products. Virology 132:282-291.

16. Figueroa, F., D. Klein, S. Tewarson, and J. Klein. 1982. Evidence for placing the $\mathrm{Neu}-\mathrm{l}$ locus within the mouse $\mathrm{H}-2 \mathrm{com}$ plex. J. Immunol. 129:2089-2093.

17. Freedman, H. A., and F. Lilly. 1975. Properties of cell lines derived from tumors induced by Friend-virus in BALB/C and BALB/c- $H-2^{\text {b }}$ mice. J. Exp. Med. 142:212-223.

18. Freedman, H. A., F. Lilly, M. Strand, and J. T. August. 1978. Variations in viral gene expression in Friend virus-transformed cell lines congenic with respect to the $H-2$ locus. Cell 13:33-40.

19. Friend, C. 1957. Cell-free transmission in adult Swiss mice of a disease having the character of a leukemia. J. Exp. Med. 105:307-318.

20. Gadzar, A. F., H. Oie, P. Lalley, W. M. Moss, J. D. Minna, and U. Francke. 1977. Identification of mouse chromosomes required for murine leukemia virus replication. Cell 11:949-956.

21. Gisselbrecht, S., S. Pozo, P. Debre, M. A. Hurot, M. J. Lacombe, and J. P. Levy. 1978. Genetic control of sensitivity to Moloneyvirus-induced leukemias in mice. I. Demonstration of multigenic control. Int. J. Cancer 21:626-634.

22. Goff, S., P. Traktman, and D. Baltimore. 1981. Isolation and properties of Moloney murine leukemia virus mutants: use of a rapid assay for release of virion reverse transcriptase. J. Virol. 38:239-248.

23. Gomard, E., Y. Henin, M. J. Colombani, and J. P. Levy. 1980 Immune response genes control $\mathrm{T}$ killer cell response against Moloney tumor antigen cytolysis regulating reactions against the best available $\boldsymbol{H}-2$ and viral antigen association. J. Exp. Med. 151:1468-1476.

24. Green, W. R. 1984. Genetic control of the induction of cytolytic T lymphocyte responses to AKR/Gross viral leukemias. I. $\mathrm{H}-2$ encoded dominant gene control. J. Immunol. 132:2658-2664.

25. Green, W. R., and M. A. Brown. 1983. The specificity of H-2-restricted cytotoxic T lymphocytes directed to AKR/Gross leukemia virus-induced tumors. II. Altered gp70 display and production of non-infectious virus particles by an insusceptible variant tumor. Eur. J. Immunol. 13:871-877.

26. Hartley, J. W., and W. P. Rowe. 1975. Clonal cell lines from a feral mouse embryo which lack host-range restrictions for murine leukemia viruses. Virology 65:128-134.

27. Hartley, J. W., N. K. Wolford, L. J. Old, and W. P. Rowe. 1977 A new class of murine leukemia virus associated with the development of spontaneous lymphomas. Proc. Natl. Acad.
Sci. USA 74:789-792.

28. Holtkamp, B., K. Fischer-Lindahl, M. Segall, and K. Rajewsky. 1979. Spontaneous loss and subsequent stimulation of $\mathbf{H}-2$ expression in clones of a heterozygous lymphoma cell line. Immunogenetics 9:405-421.

29. Jones, B., and C. A. Janeway. 1981. Cooperative interaction of B lymphocytes with antigen-specific helper T-lymphocytes is MHC restricted. Nature (London) 292:547-549.

30. Laemmli, U. K. 1970. Cleavage of structural proteins during the assembly of the head of bacteriophage T4. Nature (London) 227:680-685.

31. Lemke, H., G. J. Hammerling, and U. Hammerling. 1979. Specificity analysis with monoclonal antibodies of antigens controlled by the major histocompatibility complex and by the $\mathrm{Qa} / \mathrm{TL}$ region in mice. Immunol. Rev. 47:175-206.

32. Lilly, F., M. L. Duran-Reynals, and W. P. Rowe. 1975. Correlation of early murine leukemia virus titer and $H-2$ haplotype with spontaneous leukemia in mice of the BALB/c $\times$ AKR cross: a genetic analysis. J. Exp. Med. 141:882-889.

33. Lilly, F., and T. Pincus. 1973. Genetic control of murine viral leukemogenesis. Adv. Cancer Res. 17:231-277.

34. Lonai, P., E. Katz, A. Peled, and N. Haran-Ghera. 1981. $\mathrm{H}$-2I-linked control of immunologic resistance to viral leukemogenesis as a response to preleukemic cells. Immunogenetics 12:423-432.

35. Mak, T., C. L. Gamble, M. E. MacDonald, and A. Bernstein. 1980. Host control of sequences specific to Friend erythroleukemia virus in normal and leukemic mice. Cold Spring Harbor Symp. Quant. Biol. 44:893-899.

36. Mathieu-Mahul, D., J. Robert, S. Gisselbrech, J. P. Barque, and C. J. Larsen. 1981. Analysis of viral RNA and proteins expressed by a non-producer Friend erythroleukemia cell line (Hf1/b cell line). Leuk. Res. 5:399-411.

37. McGrath, M. S., E. Pillemer, D. Kooistra, and I. L. Weissman. 1980. The role of MuLV receptors on T-lymphoma cells in lymphoma cell proliferation. Curr. Top. Microbiol. Immunol. 11:157-183.

38. Meier, H., B. A. Taylor, M. Cherry, and R. J. Huebner. 1973 Host-gene control of type-C RNA tumor virus expression and tumorigenesis in inbred mice. Proc. Natl. Acad. Sci. USA 70:1450-1455.

39. Meruelo, D., S. H. Nimelstein, P. P. Jones, M. Lieberman, and H. O. McDevitt. 1978. Increased synthesis and expression of $\mathrm{H}-2$ antigens on thymocytes as a result of radiation leukemia virus infection: a possible mechanism for $\mathrm{H}-2$ linked control of virus-induced neoplasia. J. Exp. Med. 147:470-487.

40. Meruelo, D. J. 1979. A role for elevated $H-2$ antigen expression in resistance to neoplasia caused by radiation-induced leukemia virus; enhancement of effective tumor surveillance by killer lymphocytes. J. Exp. Med. 149:898-909.

41. Nowinski, R. C. 1976. Genetic control of natural immunity to ecotropic mouse leukemia viruses: immune response genes Infect. Immun. 13:1098.

42. Nowinski, R. C., M. Brown, T. Doyle, and R. L. Prentice. 1979. Genetic and viral factors influencing the development of spontaneous leukemia in AKR mice. Virology 96:186-204.

43. Oi, V. T., P. P. Jones, J. W. Goding, L. A. Hertzenberg, and L. A. Hertzenberg. 1978. Properties of monoclonal antibodies to mouse Ig allotypes, $H-2$, and Ia antigens. Curr. Top. Microbiol. Immunol. 81:115-129.

44. Ozato, K., N. Mayer, and D. H. Sachs. 1980. Hybridoma cell lines secreting monoclonal antibodies to mouse $\mathbf{H - 2}$ and Ia antigens. J. Immunol. 124:533-540.

45. Ozato, K., and D. H. Sachs. 1981. Monoclonal antibodies to mouse MHC antigens. III. Hybridoma antibodies reacting to antigens of the $H-2^{\mathrm{b}}$ haplotype reveal genetic control of isotype expression. J. Immunol. 126:317-321.

46. Pincus, T. 1980. The endogenous murine type $C$ viruses, $p$. 77-130. In J. R. Stephenson (ed.), Molecular biology of RNA tumor viruses. Academic Press, Inc., New York.

47. Plata, F., M. M. Goodenow, and F. Lilly. 1980. Studies of cloned friend erythroleukemia tumor cells: modulation of the tumorspecific cytolytic $\mathrm{T}$ lymphocyte response by infectious Friend 
virus production in vitro. J. Exp. Med. 151:726-742.

48. Plata, F., A. F. Tilken, J. P. Levy, and F. Lilly. 1981. Quantitative variations in the expression of $\mathrm{H}-2$ antigens on murine leukemia virus-induced tumor cells can affect the $\boldsymbol{H}-2$ restriction patterns of tumor-specific cytolytic T lymphocytes. J. Exp. Med. 154:1795-1810.

49. Racevskis, J., and G. Koch. 1977. Viral protein synthesis in Friend erythroleukemia cell lines. J. Virol. 21:328-337.

50. Rowe, W. P., W. E. Pugh, and J. W. Hartley. 1970. Plaque assay techniques for murine leukemia viruses. Virology 42:1136-1139.

51. Ruddle, N., B. S. Conta, L. Leinwald, C. Kozak, F. Ruddle, P. Besmer, and D. Baltimore. 1978. Assignment of the receptor for ectropic murine leukemia virus to mouse chromosome 5. J. Exp. Med. 148:451-465.

52. Schmidt, W., G. Atfield, and H. Festenstein. 1979. Loss of $\boldsymbol{H}-2^{\mathrm{k}}$ gene product(s) from an AKR spontaneous leukemia. Immunogenetics 8:311-321.

53. Schmidt, W., L. Leben, G. Atfield, and H. Festenstein. 1981. Variation of expression of histocompatibility antigens on tumor cells: absence of $\boldsymbol{H}-2^{\mathrm{k}}$-gene products from a Gross-virusinduced leukemia in BALB.K. Immunogenetics 14:323-339.

54. Schwartz, R. S., and S. K. Datta. 1977. Genetically determined resistance mechanisms in leukemia. Blood Cells 3:591-604.

55. Schwartzberg, P., J. Colicelli, M. L. Gordon, and S. P. Goff. 1984. Mutations in the gag gene of Moloney murine leukemia virus: effects on production of virions and reverse transcriptase. J. Virol. 49:918-924.

56. Shur, B. D., and D. Bennett. 1979. A specific defect in galactosyltransferase regulation on sperm bearing mutant alleles of the T/t locus. Dev. Biol. 71:243-259.

57. Stockert, E., E. A. Boyse, H. Sato, and K. Itakura. 1976. Heredity of the $G_{I X}$ thymocyte antigen associated with murine leukemia virus: segregation data simulating genetic linkage. Proc. Natl. Acad. Sci. USA 73:2077-2081.

58. Teich, N., J. Wyke, T. Mak, A. Bernstein, and W. Hardy. 1982. Pathogenesis of retrovirus-induced disease, p. 785-998. In R. Weiss, N. Teich, H. Varmus, and J. Coffin (ed.), RNA tumor viruses: molecular biology of tumor viruses, 2nd ed. Cold Spring Harbor Laboratory, Cold Spring Harbor, New York.

59. Tucker, H.St. G., J. Weens, P. Tshichlis, R. S. Schwartz, R. Khiroya, and J. Donnally. 1977. Influence of $\boldsymbol{H}-2$ complex on susceptibility to infection by murine leukemia virus. J. Immunol. 118:1239-1243.

60. Tung, J.-S., T. Yoshiki, and E. Fleissner. 1976. A core polyprotein of murine leukemia virus on the surface of mouse leukemia cells. Cell 9:573-578.

61. Wolfe, J. H., and K. J. Blank. 1983. Identification of a variant of Gross leukemia virus that induces disease in mice inoculated as adults. J. Exp. Med. 158:629-634.

62. Wolfe, J. H., K. J. Blank, and T. Pincus. 1981. Variation in RNA tumor virus expression in $\mathrm{H}-2$ congenic leukemia cell lines. Immunogenetics 12:187-190.

63. Wolfe, J. H., E. P. Blankenhorn, and K. J. Blank. 1984. Variation in p30-related proteins in Gross virus-induced tumor cell lines derived from $\boldsymbol{H}-2$ congenic mice. J. Virol. 49:14-19.

64. Yetter, R. A., J. W. Hartley, and H. C. Morse. 1983. H-2 linked regulation of xenotropic murine leukemia virus expression. Proc. Natl. Acad. Sci. USA 80:505-509. 